Jessica Wiederkehr, Christoph Wölper and Stephan Schulz*

\title{
Synthesis, solid-state structures and reduction reactions of heteroleptic Ge(II) and Sn(II) $\beta$-ketoiminate complexes
}

https://doi.org/10.1515/znb-2017-0098

Received June 16, 2017; accepted July 20, 2017

\begin{abstract}
A series of new heteroleptic divalent germaniun and tin complexes of the general type $\mathrm{L}^{1,4} \mathrm{GeN}\left(\mathrm{SiMe}_{3}\right)_{2}(\mathbf{1}, \mathbf{2})$ and $\mathrm{L}^{1-4} \mathrm{SnN}\left(\mathrm{SiMe}_{3}\right)_{2}(3-6)$ were synthesized by reaction of $\beta$-ketimines $\mathrm{L}^{1-4} \mathrm{H}$ with $\mathrm{Ge}\left[\mathrm{N}\left(\mathrm{SiMe}_{3}\right)_{2}\right]_{2}$ and $\mathrm{Sn}\left[\mathrm{N}\left(\mathrm{SiMe}_{3}\right)_{2}\right]_{2}$, respectively. The reaction of 3 with the strong $\mathrm{Mg}(\mathrm{I})$ reductant $\mathrm{L}^{5} \mathrm{Mg}$ yielded the heteroleptic complex $\mathrm{L}^{1} \mathrm{MgL}^{5} 7$ after ligand transfer from tin to magnesium, whereas analogous reactions of $\mathrm{L}^{4} \mathrm{GeN}\left(\mathrm{SiMe}_{3}\right)_{2} 2$ and $\mathrm{L}^{4} \mathrm{SnN}\left(\mathrm{SiMe}_{3}\right)_{2} \mathbf{6}$ with $\mathrm{L}^{5} \mathrm{Mg}$ occurred with formation of insoluble precipitates, transfer of the amido substituent from the group 14 metal to magnesium and subsequent formation of the heteroleptic magnesium complex $\mathrm{L}^{5} \mathrm{MgN}\left(\mathrm{SiMe}_{3}\right)_{2}$ (8). 1-8 were characterized by heteronuclear NMR $\left({ }^{1} \mathrm{H},{ }^{13} \mathrm{C},{ }^{119} \mathrm{Sn}\right)$ and IR spectroscopy, elemental analysis and single-crystal X-ray diffraction ( $\mathrm{L}^{4} \mathrm{SnN}\left(\mathrm{SiMe}_{3}\right)_{2}$ 6, $\left.\mathrm{L}^{1} \mathrm{MgL}^{5} 7\right)$.
\end{abstract}

Keywords: germanium; $\beta$-ketiminate; tin; X-ray crystal structure.

Dedicated to: Professor Dietrich Gudat on the occasion of his $60^{\text {th }}$ birthday.

\section{Introduction}

The interest in heavier homologues of carbenes $\left(\mathrm{R}_{2} \mathrm{C}:\right)$ has steadily increased over the last two decades and as a result, large numbers of silylenes ( $\mathrm{R}_{2} \mathrm{Si}$ ), germylenes ( $\left.\mathrm{R}_{2} \mathrm{Ge}:\right)$, stannylenes ( $\left.\mathrm{R}_{2} \mathrm{Sn}:\right)$, and plumbylenes $\left(\mathrm{R}_{2} \mathrm{~Pb}:\right)$ have been synthesized and structurally characterized [1-5]. The stability of these divalent species, where the formal oxidation state of the tetrele atom is $\mathrm{M}^{\mathrm{II}}$, was found

\footnotetext{
*Corresponding author: Stephan Schulz, Institute of Inorganic Chemistry, University of Duisburg-Essen, and Center for Nanointegration Duisburg-Essen (Cenide), 45117 Essen, Germany, Tel.: +49 0201-1834635, Fax: + 49 0201-1834635,

E-mail: stephan.schulz@uni-due.de

Jessica Wiederkehr and Christoph Wölper: Institute of Inorganic Chemistry, University of Duisburg-Essen, 45117 Essen, Germany
}

to steadily increase with increasing atomic number as can already be seen when comparing the group 14 dihalides. While $\mathrm{PbCl}_{2}, \mathrm{SnCl}_{2}$ and $\mathrm{GeCl}_{2} \cdot$ (dioxane) are stable compounds in solution and in the solid state, $\mathrm{SiCl}_{2}$ was only recently isolated as a carbene-stabilized compound IPr-SiCl 2 (IPr=1,3-bis(2,6-iPr $)$ imidazol-2-ylidene) [6, 7]. In addition, detailed reactivity studies of these heavier carbenes clearly revealed differences to carbenes, which mainly result from their different electronic structure. The ground state of $\mathrm{H}_{2} \mathrm{C}$ : is a triplet, whereas $\mathrm{H}_{2} M$ : $(M=\mathrm{Si}, \mathrm{Ge}$, $\mathrm{Sn}, \mathrm{Pb}$ ) show a singlet ground state, resulting in an empty $p$ orbital and a filled $s$ orbital. According to quantum chemical calculations, the singlet-triplet energy differences $\Delta E_{\mathrm{ST}}\left[\Delta E_{\mathrm{ST}}=E\right.$ (triplet) $-E$ (singlet) $]$ steadily increase from -14.0 $(M=\mathrm{C}), 16.7(M=\mathrm{Si}), 21.8(M=\mathrm{Ge}), 24.8(M=\mathrm{Sn})$ to finally $34.8(M=\mathrm{Pb}) \mathrm{kcal} \mathrm{mol}^{-1}$ [8]. In addition, the relative stabilities of the monomeric metal organic species $\mathrm{R}_{2} M$ : ( $M=\mathrm{C}-\mathrm{Pb} ; \mathrm{R}=$ alkyl, aryl) compared to the corresponding dimeric species, $\mathrm{R}_{2} M=M \mathrm{R}_{2}$, was also found to increase with increasing atomic number of the tetrele atom.

The first stable metal organic germylenes and stannylenes $\left[\left(\mathrm{Me}_{3} \mathrm{Si}\right)_{2} \mathrm{CH}\right]_{2} M(M=\mathrm{Ge}, \mathrm{Sn})$ were reported by Lappert et al. [9-11] almost 40 years ago. Since then, a large variety of compounds of this type have been synthesized, and in particular $\mathrm{N}, \mathrm{N}^{\prime}$-chelating organic substituents including sterically bulky amidinate, guanidinate and $\beta$ diketiminate ligands as well as N,O chelating substituents have been successfully used for the stabilization of the desired class of compounds [12-22]. These compounds are of interest since they can both react as Lewis base due to the presence of an electron lone pair and as Lewis acid due to an empty (acceptor) orbital. They have been widely applied in different reactions with organic substrates and in catalysis [23, 24], in particular tin complexes containing $\mathrm{N}, \mathrm{N}^{\prime}$ - and $\mathrm{N}, \mathrm{O}$-chelating ligands have been shown to exhibit promising activities in ring-opening polymerization (ROP) of cyclic esters [25-27]. In addition, they can serve as suitable starting reagents in reduction reactions for the synthesis of low-valent, including cluster-type, compounds. For instance, the treatment of the heteroleptic $\beta$-diketiminate complex [ $\left.\mathrm{HC}(\mathrm{CMeNAr})_{2}\right] \mathrm{SnCl}$ with $\mathrm{KC}_{8}$ or $\mathrm{LiAlH}_{4}$ resulted in the formation of the homoleptic complex [HC(CMeNAr) $\left.{ }_{2}\right]_{2} \mathrm{Sn}[28]$, while reactions of the heteroleptic 
amidotin chlorides $\left\{\mathrm{Sn}\left[\mathrm{N}(\operatorname{dipp}) \mathrm{SiMe}_{2} \mathrm{R}\right](\mu \text {-Cl })\right\}_{2}(\operatorname{dipp}=2,6$ $i \mathrm{Pr}_{2} \mathrm{C}_{6} \mathrm{H}_{3} ; \mathrm{R}=\mathrm{Me}, \mathrm{Ph}$ ) with $\mathrm{Li}\left[\mathrm{BHs}-\mathrm{Bu}_{3}\right]$ yielded two large metalloid $\mathrm{Sb}_{15}$ clusters $\left.\left[\mathrm{Sn}_{9}\left\{\mathrm{SnN}(\text { dipp}) \mathrm{SiMe}_{2} \mathrm{R}\right)\right\}_{6}\right]$ containing unprecedented body-centered metal cores [29]. Bulky amido substituents generally show potential in the stabilization of low-valent main group metal and transition metal complexes including multiply-bonded and clustertype species [30] as was previously shown for terphenyl [31-34] and silyl substituents [35-38].

We recently demonstrated that $\left(\operatorname{trip}_{2} \mathrm{Sn}\right)_{2}$ (trip $=2,4,6$ $\left.i \mathrm{Pr}_{3} \mathrm{C}_{6} \mathrm{H}_{2}\right)$ reacts with the strong $\mathrm{Mg}(\mathrm{I})$ reductant $(\mathrm{LMg})_{2}$ $\left(\mathrm{L}=\mathrm{HC}[\mathrm{C}(\mathrm{Me}) \mathrm{N}(\mathrm{dipp})]_{2}\right)$ with $\mathrm{Sn}-\mathrm{C}$ bond cleavage and formation of the novel metalloid tin cluster $\mathrm{Sn}_{10} \operatorname{trip}_{8}$ [39]. We therefore became interested to extend these reduction reaction studies to divalent heteroleptic germanium and tin compounds containing a sterically demanding, chelating $\beta$-ketiminate ligand, which was expected to be rather strongly bonded and to be able to stabilize low-valent $\mathrm{Ge}$ and Sn cluster species through its high steric demand, as well as a weakly bonded bis(trimethylsilyl)amide ligand as rather weakly bonded leaving group.

Herein we report on the synthesis of a series of heteroleptic divalent germanium and tin $\beta$-ketiminate amide complexes of the general type $\mathrm{L}^{1-4} \mathrm{EN}\left(\mathrm{SiMe}_{3}\right)_{2}(\mathrm{E}=\mathrm{Ge}$, $\mathrm{Sn})$. The $\beta$-ketiminate ligands either contain a sterically demanding substituent attached to the coordinating $\mathrm{N}$ atom or an alkyl group with a terminal $\mathrm{NR}_{2}$ moiety, which may serve as pendant side-arm donor and can further coordinate to the metal center. Selected complexes were then investigated in reduction reactions with a strong $\mathrm{Mg}(\mathrm{I})$ reductant.

\section{Results and discussion}

The germanium $\mathrm{L}^{1,4} \mathrm{GeN}\left(\mathrm{SiMe}_{3}\right)_{2} \quad(\mathbf{1}, \quad 2)$ and tin $\beta$ ketiminate complexes $\mathrm{L}^{1-4} \mathrm{SnN}\left(\mathrm{SiMe}_{3}\right)_{2}$ (3-6) were synthesized (Scheme 1) by reaction of equimolar amounts of $\mathrm{E}\left[\mathrm{N}\left(\mathrm{SiMe}_{3}\right)_{2}\right]_{2}(\mathrm{E}=\mathrm{Ge}, \mathrm{Sn})$ with the corresponding $\beta$ ketimines $\quad \mathrm{L}^{1-4} \mathrm{H} \quad\left(\mathrm{L}^{1}=\mathrm{OC}(\mathrm{Me}) \mathrm{C}(\mathrm{H}) \mathrm{C}(\mathrm{Me}) \mathrm{NCH}_{2} \mathrm{CH}_{2} \mathrm{NMe}_{2}\right.$, $\mathrm{L}^{2}=\mathrm{OC}(\mathrm{Me}) \mathrm{C}(\mathrm{H}) \mathrm{C}(\mathrm{Me}) \mathrm{NCH}_{2} \mathrm{CH}_{2} \mathrm{NEt}_{2}, \quad \mathrm{~L}^{3}=\mathrm{OC}(\mathrm{Me}) \mathrm{C}(\mathrm{H})$

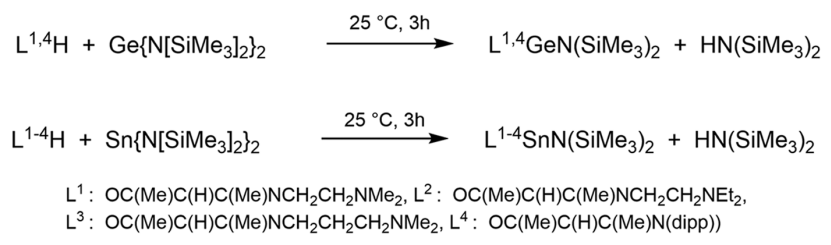

Scheme 1: Synthesis of the complexes 1-6.
$\left.\mathrm{C}(\mathrm{Me}) \mathrm{NCH}_{2} \mathrm{CH}_{2} \mathrm{CH}_{2} \mathrm{NMe}_{2}, \mathrm{~L}^{4}=\mathrm{OC}(\mathrm{Me}) \mathrm{C}(\mathrm{H}) \mathrm{C}(\mathrm{Me}) \mathrm{N}(\operatorname{dipp})\right)$ at ambient temperature. The reactions proceeded smoothly with elimination of the amine $\mathrm{HN}\left(\mathrm{SiMe}_{3}\right)_{2}$ and subsequent formation of the expected heteroleptic $\beta$-ketiminate complexes (Scheme 2) in high yields (67-96\%).

The ${ }^{1} \mathrm{H}$ NMR spectra of $\mathbf{1}-\mathbf{6}$ show the expected resonances of the chelating $\beta$-ketiminate unit $(\mathrm{CH}, \mathrm{NCMe}$, OCMe) and the expected resonances of the silyl groups between $0.30 \mathrm{ppm}\left(\mathrm{L}^{4} \mathrm{SnN}\left(\mathrm{SiMe}_{3}\right)_{2}\right.$ 6) and $0.45 \mathrm{ppm}$ $\left(\mathrm{L}^{1} \mathrm{SnN}\left(\mathrm{SiMe}_{3}\right)_{2} 3\right)$. Additional resonances due to the $\beta$-ketoiminate-imine-substituents (NR) were recorded. In the case of $\mathbf{2}$ and $\mathbf{6}$, two well separated septets and four distinguished doublets (Supporting information, Figs. S1, S19) with a relative intensity of 3:3:6:6:6:6 for the diastereotopic protons of the dipp substituent were observed, while the ${ }^{1} \mathrm{H}$ NMR spectra of $\mathbf{1}$ and $\mathbf{3}-\mathbf{5}$ show two multiplets of equal relative intensity for the methylene protons of the ethylamino and propylamino group $\left(\mathrm{CH}_{2} \mathrm{CH}_{2} \mathrm{NR}_{2}\right.$, $\mathrm{CH}_{2} \mathrm{CH}_{2} \mathrm{CH}_{2} \mathrm{NR}_{2} \mathrm{R}=\mathrm{Me}$, Et, Figs. S4, S7, S11, S15). These findings either result from the chirality of the molecules due to the pseudo-tetrahedral environment of the $\mathrm{Ge}$ and $\mathrm{Sn}$ atoms or point to a hindered rotation around the $\mathrm{N}-\mathrm{C}_{\mathrm{ipso}}$ single bond $(\mathbf{2}, \mathbf{6})$, according to which the $i \mathrm{Pr}$ groups become magnetically inequivalent, or a coordination of the sidearm $\mathrm{NR}_{2}$ group in solution to the Lewis acidic germanium and tin atom (1, 3-5), respectively. The ${ }^{119} \mathrm{Sn}$ NMR resonances of 3-6 were detected in the range between $-89 \mathrm{ppm}\left(\mathrm{L}^{4} \mathrm{SnN}\left(\mathrm{SiMe}_{3}\right)_{2} 6\right)$ and $-221 \mathrm{ppm}$ $\left(\mathrm{L}^{1} \mathrm{SnN}\left(\mathrm{SiMe}_{3}\right)_{2} 3\right)$.

Orange crystals of $\mathbf{6}$ suitable for an X-ray structure determination were obtained after storage of a concentrated solution of 6 in $n$-hexane at $-30^{\circ} \mathrm{C}$. Compound 6 crystallizes in the monoclinic space group $P 2_{1} / n$ with one molecule in the asymmetric unit (Fig. 1).

The central tin atom is coordinated by a chelating $\beta$-ketiminato ligand $\mathrm{L}^{4}$ and one amide $\left(\left[\mathrm{N}\left(\mathrm{SiMe}_{3}\right)_{2}\right]^{-}\right)$ligand. This leads to a trigonal pyramidal environment of the tin atom. Even though the Sn1-N1 bond (see caption Fig. 1) is longer than the average $\mathrm{Sn}-\mathrm{N}$ bond in $\beta$-ketiminato complexes [40, 41], this value is still within the typical range. The Sn1-01 bond length also is equal to the average value derived from the database, whereas the Sn1-N2 bond is longer than the average but well within the typical range of $\mathrm{Sn}-\mathrm{N}$ bonds to $\left[\mathrm{N}\left(\mathrm{SiMe}_{3}\right)_{2}\right]^{-}$ligands [42]. This elongation may be attributed to the high steric demand of the $\mathrm{SiMe}_{3}$ groups. The three bonds are roughly perpendicular with $\mathrm{N} / \mathrm{O}-\mathrm{Sn}-\mathrm{N}$ bond angles ranging between $84.52(5)^{\circ}$ and $99.77(5)^{\circ}$. The central $\mathrm{NOC}_{3}$ unit of the $\beta$-ketiminato ligand is almost planar (r.m.s. deviation from best plane $0.0192 \AA$ ) and the tin atom is slightly shifted from this plane 


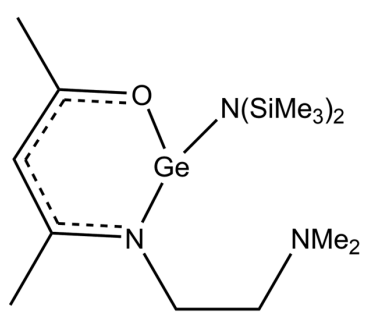

$\mathrm{L}^{1} \mathrm{GeN}\left(\mathrm{SiMe}_{3}\right)_{2}(\mathbf{1})$

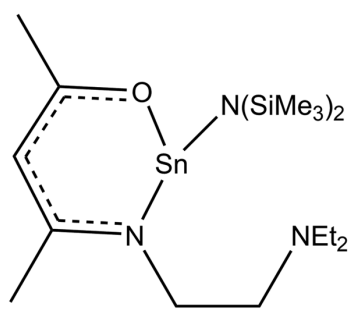

$\mathrm{L}^{2} \mathrm{SnN}\left(\mathrm{SiMe}_{3}\right)_{2}(4)$

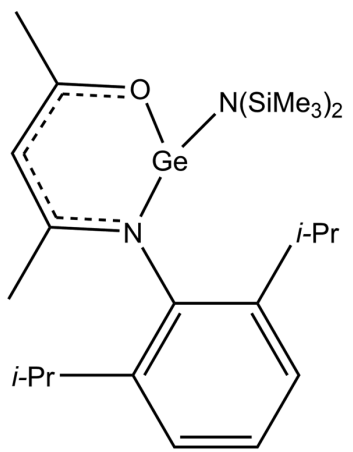

$\mathrm{L}^{4} \mathrm{GeN}\left(\mathrm{SiMe}_{3}\right)_{2}(2)$

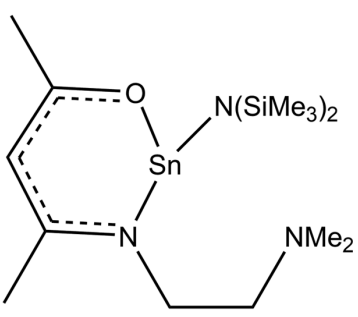

$\mathrm{L}^{1} \mathrm{SnN}\left(\mathrm{SiMe}_{3}\right)_{2}(\mathbf{3})$

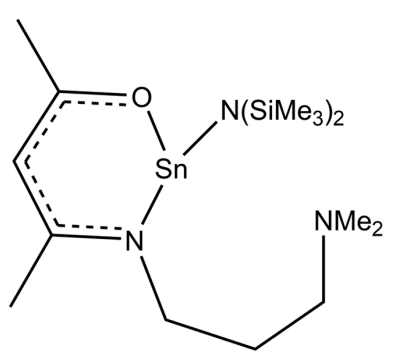

$\mathrm{L}^{3} \mathrm{SnN}\left(\mathrm{SiMe}_{3}\right)_{2}(\mathbf{5})$

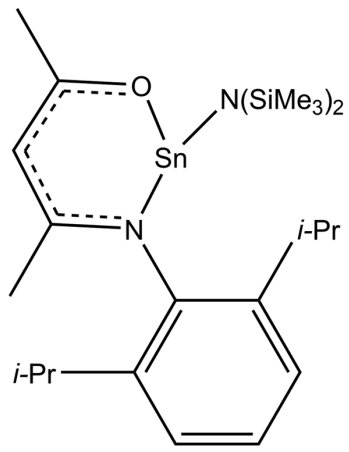

$\mathrm{L}^{4} \mathrm{SnN}\left(\mathrm{SiMe}_{3}\right)_{2}(6)$

Scheme 2: Schematic drawing of the complexes 1-6.

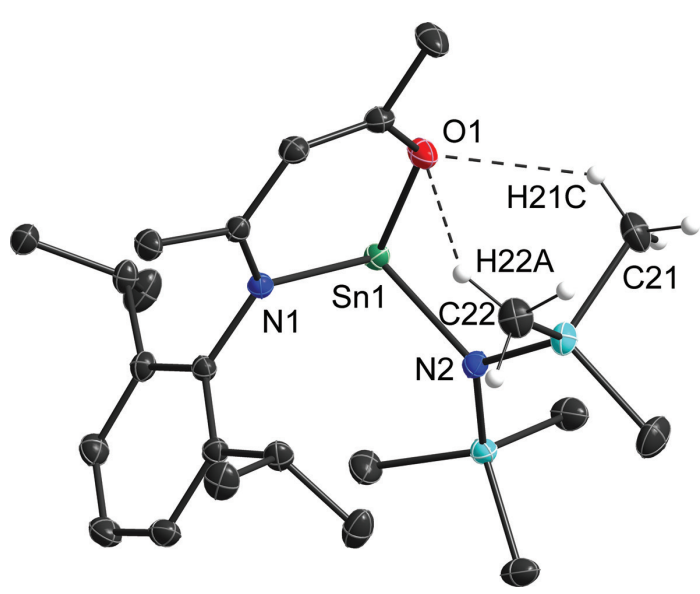

Fig. 1: Solid-state structure of 6 . Non-H atoms are shown as displacement ellipsoids at $50 \%$ probability levels, $\mathrm{H}$ atoms are omitted for clarity except for those engaged in intramolecular interactions. Selected bond lengths $(\AA)$ and angles (deg): Sn(1)-O(1) 2.1067(13), Sn(1)-N(2) 2.1264(14), Sn(1)-N(1) 2.2656(14); O(1)-Sn(1)-N(2) 96.93(5), O(1)-Sn(1)-N(1) 84.52(5), $\mathrm{N}(2)-\mathrm{Sn}(1)-\mathrm{N}(1)$ 99.77(5), C(1)-O(1)-Sn(1) 129.62(11), C(3)-N(1)C(6) 120.89(13), C(3)-N(1)-Sn(1) 125.19(11), C(6)-N(1)-Sn(1) 113.58(10), Si(2)-N(2)-Si(3) 124.61(8), Si(2)-N(2)-Sn(1) 119.45(7), $\mathrm{Si}(3)-\mathrm{N}(2)-\mathrm{Sn}(1) 110.92(7), \mathrm{C}(21)-\mathrm{H}(21) \mathrm{C} \cdots \mathrm{O}$ (1) 131.8, C(22)-H(22) a.. O(1) 126.7.
[0.330(3) $\AA]$ in the direction away from the $\left[\mathrm{N}\left(\mathrm{SiMe}_{3}\right)_{2}\right]^{-}$ group. This may again be explained by the high steric demand of the $\mathrm{SiMe}_{3}$ groups. Two short intramolecular

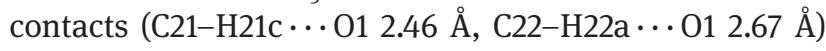
support the conformation of the molecule.

The potential capability of these heteroleptic complexes 1-6 to serve as starting reagents in reduction reactions for the synthesis of metalloid tin and germanium clusters was exemplarily investigated in the reaction of $\mathrm{L}^{1} \mathrm{SnN}\left(\mathrm{SiMe}_{3}\right)_{2} 3$ with the strong $\mathrm{Mg}(\mathrm{I})$ reductant $\left[\mathrm{L}^{5} \mathrm{Mg}\right]_{2}$ $\left(\mathrm{L}^{5}=(\operatorname{dipp}) \mathrm{NC}(\mathrm{Me}) \mathrm{C}(\mathrm{H}) \mathrm{C}(\mathrm{Me}) \mathrm{N}(\operatorname{dipp})\right)$ [43, 44]. However, in addition to the formation of a black insoluble precipitate, most likely elemental tin, which clearly proves the reduction of 3, we observed the formation of the heteroleptic complex $\mathrm{L}^{1} \mathrm{MgL}^{5} 7$, which is formed by a ligand transfer reaction of $\mathrm{L}^{5}$ from the tin to the magnesium atom. Comparable results were obtained from the reactions of $\left[\mathrm{L}^{5} \mathrm{Mg}\right]_{2}$ with $\mathrm{L}^{4} \mathrm{GeN}\left(\mathrm{SiMe}_{3}\right)_{2} \mathbf{2}$ and $\mathrm{L}^{4} \mathrm{SnN}\left(\mathrm{SiMe}_{3}\right)_{2} \mathbf{6}$, which both yielded the known $\beta$-diketiminato magnesium amide $\mathrm{L}^{5} \mathrm{MgN}\left(\mathrm{SiMe}_{3}\right)_{2} 8$ as was demonstrated by in situ ${ }^{1} \mathrm{H}$ NMR spectroscopy [45]. In contrast to the reactions with 3, which occurred with transfer of the $\beta$-ketiminato ligand $\mathrm{L}^{1}$ to the magnesium atom, the reaction with $\mathbf{2}$ and $\mathbf{6}$ led to 
a transfer of the bis(trimethylsilyl)amido moiety from the group 14 metal center to magnesium. Again, both reactions proceeded with formation of insoluble precipitates, most likely elemental germanium and tin, as well as the formation of additional products according to in situ ${ }^{1} \mathrm{H}$ NMR spectroscopy. Unfortunately, these compounds could not be identified so far. However, these reactions clearly show that both $\mathrm{Ge}-\mathrm{N}$ and $\mathrm{Sn}-\mathrm{N}$ bonds can be cleaved by reaction with the strong $\mathrm{Mg}(\mathrm{I})$ reductant.

Crystals of 7 suitable for a single crystal X-ray diffraction study were obtained after storage of a solution of 7 in $n$-hexane for $2 \mathrm{~d}$ at $-30^{\circ} \mathrm{C}$ (Fig. 2).

Compound 7 crystallizes in the monoclinic space group $C 2 / c$ with the molecule placed on a general position. The central $\mathrm{Mg}$ atom is coordinated by one $\mathrm{L}^{5}$ and one $\mathrm{L}^{1}$ ligands both in a chelating fashion. The resulting environment of the $\mathrm{Mg}$ atom is best described as distorted trigonal bipyramidal, in which $\mathrm{O} 1$ and $\mathrm{N} 4$ adopt the apical positions. The corresponding bond angle however deviates approximately $20^{\circ}$ from the expected linearity. The distortion also manifests itself in the bond angles in the equatorial positions. The N1-Mg1-N2 bond angle is determined by the bite angle of the ligand and is thus smaller

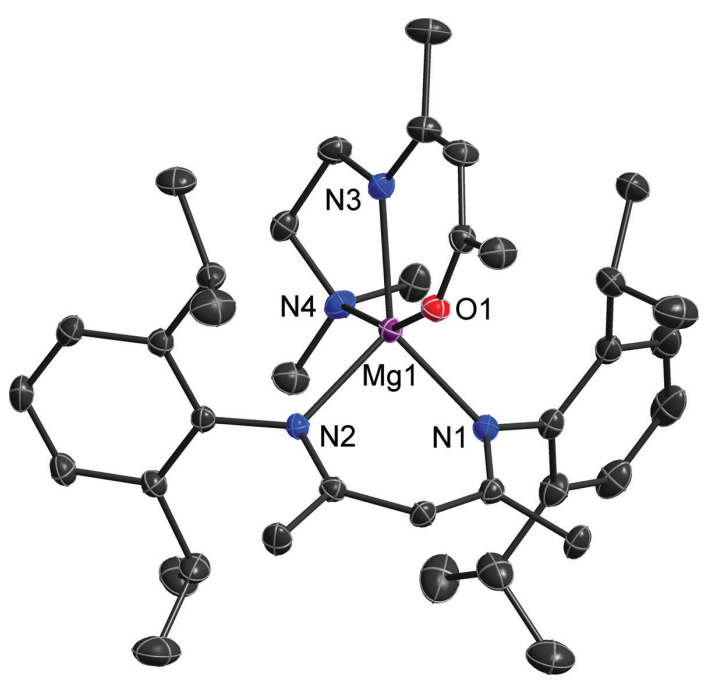

Fig. 2: Solid-state structure of 7. Non-H atoms are shown as displacement ellipsoids at $50 \%$ probability levels, $\mathrm{H}$ atoms and a second orientation of the disordered side-arm are omitted for clarity. Selected bond lengths $(\AA)$ and angles (deg): $\mathrm{Mg}(1)-\mathrm{O}(1)$ 1.9903(7), Mg(1)-N(1) 2.1055(8), Mg(1)-N(2) 2.1144(8), Mg(1)-N(3') 2.152(8), $\mathrm{Mg}(1)-\mathrm{N}(3)$ 2.166(4), $\mathrm{Mg}(1)-\mathrm{N}(4)$ 2.2669(9); O(1)$\mathrm{Mg}(1)-\mathrm{N}(1)$ 94.26(3), O(1) $-\mathrm{Mg}(1)-\mathrm{N}(2)$ 93.25(3), N(1) $-\mathrm{Mg}(1)-\mathrm{N}(2)$ 91.64(3), O(1) $-\mathrm{Mg}(1)-\mathrm{N}\left(3^{\prime}\right)$ 85.5(2), N(1) $-\mathrm{Mg}(1)-\mathrm{N}\left(3^{\prime}\right)$ 126.55(12), $\mathrm{N}(2)-\mathrm{Mg}(1)-\mathrm{N}\left(3^{\prime}\right)$ 141.80(12), O(1) $-\mathrm{Mg}(1)-\mathrm{N}(3)$ 84.58(10), N(1)$\mathrm{Mg}(1)-\mathrm{N}(3)$ 137.20(6), N(2) $-\mathrm{Mg}(1)-\mathrm{N}(3)$ 131.17(6), O(1) $-\mathrm{Mg}(1)-\mathrm{N}(4)$ 160.99(3), $\mathrm{N}(1)-\mathrm{Mg}(1)-\mathrm{N}(4)$ 98.89(3), $\mathrm{N}(2)-\mathrm{Mg}(1)-\mathrm{N}(4)$ 100.01(3), $N\left(3^{\prime}\right)-M g(1)-N(4) 75.6(2), N(3)-M g(1)-N(4) 76.44(10)$. $\left[91.64(3)^{\circ}\right]$ than the ideal value of $120^{\circ}$. Since $\mathrm{Mg}$ is on the same plane with $\mathrm{N} 1$ and N3/N3' (r.m.s. deviation $0.000 \AA$ and $0.0049 \AA$, resp.) the other equatorial bond angles necessarily have to be larger than the ideal value. Mg1 is on the plane of the $\mathrm{NOC}_{3}$ backbone of $\mathrm{L}^{1}$ [deviation from best plane 0.016(5) $\AA$ and 0.350(3) $\AA$, resp.], but significantly off the plane of the $\mathrm{N}_{2} \mathrm{C}_{3}$ backbone of $\mathrm{L}^{5}$ [deviation from best plane 0.9809(10) $\AA$ ]. The bond lengths match well with results from the CSD [46]. As was expected the more weakly coordinated side-arm donor N4 shows an elongated bond to Mg1.

\section{Conclusion}

Heteroleptic divalent germanium $\mathrm{L}^{1,4} \mathrm{GeN}\left(\mathrm{SiMe}_{3}\right)_{2}$ (1, 2) and tin complexes $\mathrm{L}^{1-4} \mathrm{SnN}\left(\mathrm{SiMe}_{3}\right)_{2}\left(\mathbf{3}^{-6}\right)$ are easily accessible by amide elimination reactions of $\beta$-ketimines $\mathrm{L}^{1-4} \mathrm{H}$ with $\mathrm{Ge}\left[\mathrm{N}\left(\mathrm{SiMe}_{3}\right)_{2}\right]_{2}$ and $\mathrm{Sn}\left[\mathrm{N}\left(\mathrm{SiMe}_{3}\right)_{2}\right]_{2}$, respectively, under mild reaction conditions. 3 reacts with the strong $\mathrm{Mg}(\mathrm{I})$ reductant $\mathrm{L}^{5} \mathrm{Mg}$ with transfer of the $\beta$-ketiminate ligand $\left(\mathrm{L}^{1}\right)$ from tin to magnesium and formation of the heteroleptic complex $\mathrm{L}^{1} \mathrm{MgL}^{5}$ 7, whereas analogous reduction reactions of $\mathrm{L}^{4} \mathrm{GeN}\left(\mathrm{SiMe}_{3}\right)_{2} 2$ and $\mathrm{L}^{4} \mathrm{SnN}\left(\mathrm{SiMe}_{3}\right)_{2} 6$ occurred with transfer of the amido substituent and formation of the known heteroleptic magnesium complex $\mathrm{L}^{5} \mathrm{MgN}\left(\mathrm{SiMe}_{3}\right)_{2}$ (8).

\section{Experimental section}

All manipulations were performed under Ar. Solvents were carefully dried with $\mathrm{Na} / \mathrm{K}$ and degassed prior to use. $\left[\mathrm{L}^{5} \mathrm{Mg}\right]_{2}$ was prepared according to literature methods $[43,44] .{ }^{1} \mathrm{H}$ NMR, ${ }^{13} \mathrm{C}\left\{{ }^{1} \mathrm{H}\right\}$ and ${ }^{119} \mathrm{Sn}\left\{{ }^{1} \mathrm{H}\right\}$ NMR spectra were recorded with a Bruker DMX 300 spectrometer and are referenced to internal $\mathrm{C}_{6} \mathrm{D}_{5} \mathrm{H}\left({ }^{1} \mathrm{H}: \delta=7.16 \mathrm{ppm} ;{ }^{13} \mathrm{C}\right.$ : $\delta=128.0 \mathrm{ppm})$ and $\mathrm{Me}_{4} \mathrm{Sn}\left({ }^{119} \mathrm{Sn}\left\{{ }^{1} \mathrm{H}\right\}\right)$ [47]. IR spectra were recorded with an ALPHA-T FTIR spectrometer equipped with a single-reflection ATR sampling module. Melting points were measured in sealed capillaries. Elemental analyses were performed at the Elementaranalyse Labor of the University of Essen.

\subsection{General synthesis of $\beta$-ketimines $\mathrm{L}^{1-4} \mathrm{H}$}

The $\beta$-ketimine ligands $\mathrm{L}^{1-4} \mathrm{H}$ with different additional side-arm donors where synthesized according to the 
following general procedure, which is slightly modified regarding the literature procedures using the corresponding (di)amine ( $\mathrm{L}^{1} \mathrm{H}: \mathrm{N}, \mathrm{N}$-dimethylethylenediamine, $\mathrm{L}^{2} \mathrm{H}$ : $\mathrm{N}, \mathrm{N}$-diethylethylenediamine, $\mathrm{L}^{3} \mathrm{H}: \quad 3$-(dimethylamino)1-propylamine, $\mathrm{L}^{4} \mathrm{H}: 2$,6-diisopropylaniline) [48-50]. $\mathrm{L}^{1-4} \mathrm{H}$ were obtained as orange liquids in almost quantitative yield.

\subsection{1 $\mathrm{L}^{1} \mathrm{H}$}

$\mathrm{N}, \mathrm{N}$-Dimethylethylenediamine $(9.92 \mathrm{~mL}, 0.091 \mathrm{~mol})$ was added to acetyl acetone $(10.26 \mathrm{~mL}, 0.100 \mathrm{~mol})$. The mixture was stirred at ambient temperature for $3 \mathrm{~h}$ and $\mathrm{L}^{1} \mathrm{H}$ was isolated as an orange liquid after removal of the volatiles in vacuum. Yield: $15.3 \mathrm{~g}$, (99\%). - Elemental analysis: calcd. (found): H 62.5 (61.9), C 10.7 (10.8), N 14.5 (14.6). $-{ }^{1} \mathrm{H}$ NMR (300 MHz, $\left.\mathrm{C}_{6} \mathrm{D}_{6}, 25^{\circ} \mathrm{C}\right): \delta=1.86$ (s, $6 \mathrm{H}, \mathrm{OCCH}_{3}$ and $\left.\mathrm{NCCH}_{3}\right), 2.18\left(\mathrm{~s}, 6 \mathrm{H}, \mathrm{N}\left(\mathrm{CH}_{3}\right)_{2}\right), 2.38\left(\mathrm{t},{ }^{3} J_{\mathrm{H}, \mathrm{H}}=6.3 \mathrm{~Hz}, 2\right.$ $\left.\mathrm{H}, \mathrm{CH}_{2} \mathrm{CH}_{2} \mathrm{NMe}_{2}\right), 3.24\left(\mathrm{~m},{ }^{3} \mathrm{H}_{\mathrm{H}, \mathrm{H}}=6.3 \mathrm{~Hz}, 2 \mathrm{H}, \mathrm{CH}_{2} \mathrm{CH}_{2} \mathrm{NMe}_{2}\right)$, 4.88 (s, 1 H, CH), 10.71 (s, 1 H, NH). - IR (ATR): $v=2943$, 2861, 2819, 2767, 1609, 1564, 1513, 1440, 1285, 1193, 1110, $1019,732,652 \mathrm{~cm}^{-1}$.

\subsection{2 $L^{2} H$}

Yield: $18.0 \mathrm{~g},(100 \%) .-{ }^{1} \mathrm{H}$ NMR $\left(300 \mathrm{MHz}, \mathrm{C}_{6} \mathrm{D}_{6}, 25^{\circ} \mathrm{C}\right)$ : $\delta=0.86\left(\mathrm{t}, 6 \mathrm{H}, \mathrm{N}\left(\mathrm{CH}_{2} \mathrm{CH}_{3}\right)_{2}\right), 1.46$ (s, $\left.3 \mathrm{H}, \mathrm{NCCH}_{3}\right), 1.82$ (s, $\left.3 \mathrm{H}, \mathrm{OCCH}_{3}\right), 2.38\left(\mathrm{~m}, 6 \mathrm{H}\right.$, overlapping signals $\mathrm{CH}_{2} \mathrm{CH}_{2} \mathrm{~N}-$ $\left.\left(\mathrm{CH}_{2} \mathrm{CH}_{3}\right)_{2}\right), 3.06\left(\mathrm{~m},{ }^{3} \mathrm{H}_{\mathrm{H}, \mathrm{H}}=6.8 \mathrm{~Hz}, 1 \mathrm{H}, \mathrm{CH}_{2} \mathrm{CH}_{2} \mathrm{NEt}_{2}\right), 3.32$ $\left(\mathrm{m},{ }^{3} \mathrm{H}_{\mathrm{H}, \mathrm{H}}=6.8 \mathrm{~Hz}, 1 \mathrm{H}, \mathrm{CH}_{2} \mathrm{CH}_{2} \mathrm{NEt}_{2}\right), 4.70(\mathrm{~s}, 1 \mathrm{H}, \mathrm{CH})$.

\subsection{3 $L^{3} H$}

Yield: $15.9 \mathrm{~g},(95 \%)$. Elemental analysis: calcd. (found): $\mathrm{H}$ 65.2 (64.7), C 10.6 (10.2), N 15.2 (15.0). - ${ }^{1} \mathrm{H}$ NMR (300 MHz, $\left.\mathrm{C}_{6} \mathrm{D}_{6}, 25^{\circ} \mathrm{C}\right): \delta=1.63\left(\mathrm{~m},{ }^{3} J_{\mathrm{H}, \mathrm{H}}=7.3 \mathrm{~Hz}, 2 \mathrm{H}, \mathrm{CH}_{2} \mathrm{CH}_{2} \mathrm{CH}_{2} \mathrm{NMe}_{2}\right)$, $1.87\left(\mathrm{~s}, 6 \mathrm{H}, \mathrm{OCCH}_{3}\right.$ and $\left.\mathrm{NCCH}_{3}\right), 2.12\left(\mathrm{~s}, 6 \mathrm{H}, \mathrm{N}\left(\mathrm{CH}_{3}\right)_{2}\right), 2.24$ $\left(\mathrm{t},{ }^{3} \mathrm{H}_{\mathrm{H}, \mathrm{H}}=6.9 \mathrm{~Hz}, 2 \mathrm{H}, \mathrm{CH}_{2} \mathrm{CH}_{2} \mathrm{CH}_{2} \mathrm{NMe}_{2}\right), 3.23\left(\mathrm{q},{ }^{3} J_{\mathrm{H}, \mathrm{H}}=6.5 \mathrm{~Hz}\right.$, $\left.2 \mathrm{H}, \mathrm{CH}_{2} \mathrm{CH}_{2} \mathrm{CH}_{2} \mathrm{NMe}_{2}\right), 4.88$ (s, $\left.1 \mathrm{H}, \mathrm{CH}\right), 10.78(\mathrm{~s}, 1 \mathrm{H}, \mathrm{NH})$. IR (ATR): $v=2944,2860,2817,2766,1608,1574,1511,1439$, 1295, 1260, 1097, 1016, 795, 734, $637 \mathrm{~cm}^{-1}$.

\subsection{4 $\mathrm{L}^{4} \mathrm{H}$}

Yield: $21.2 \mathrm{~g},(90 \%) .-{ }^{1} \mathrm{H}$ NMR (300 MHz, $\left.\mathrm{C}_{6} \mathrm{D}_{6}, 25^{\circ} \mathrm{C}\right)$ : $\delta=1.17\left(\mathrm{~d},{ }^{3} J_{\mathrm{H}, \mathrm{H}}=6.9 \mathrm{~Hz}, 6 \mathrm{H}, \mathrm{CH}\left(\mathrm{CH}_{3}\right)_{2}\right), 1.25\left(\mathrm{~d},{ }^{3} J_{\mathrm{H}, \mathrm{H}}=7.0 \mathrm{~Hz}\right.$, $\left.6 \mathrm{H}, \mathrm{CH}\left(\mathrm{CH}_{3}\right)_{2}\right), 1.65\left(\mathrm{~s}, 6 \mathrm{H}, \mathrm{NCCH}_{3}\right), 2.10\left(\mathrm{~s}, 6 \mathrm{H}, \mathrm{OCCH}_{3}\right)$,
3.06 (sept, $\left.{ }^{3} J_{\mathrm{H}, \mathrm{H}}=6.9 \mathrm{~Hz}, 2 \mathrm{H}, \mathrm{CH}\left(\mathrm{CH}_{3}\right)_{2}\right), 5.25(\mathrm{~s}, 1 \mathrm{H}, \mathrm{CH})$, $12.09(\mathrm{~s}, 1 \mathrm{H}, \mathrm{NH})$.

\subsection{General synthesis of germanium complexes $\mathrm{L}^{1,4} \mathrm{GeN}\left(\mathrm{SiMe}_{3}\right)_{2}$}

A solution of $\mathrm{LH}\left(\mathrm{L}^{1} \mathrm{H}: 0.216 \mathrm{~g}, 1.3 \mathrm{mmol} ; \mathrm{L}^{4} \mathrm{H}: 0.330 \mathrm{~g}\right.$, $1.3 \mathrm{mmol}$ ) in $10 \mathrm{~mL}$ of hexane was added slowly to a solution of $\mathrm{Ge}\left[\mathrm{N}\left(\mathrm{SiMe}_{3}\right)_{2}\right]_{2}(0.500 \mathrm{~g}, 1.3 \mathrm{mmol})$ in $10 \mathrm{~mL}$ of hexane at $0^{\circ} \mathrm{C}$ and stirred for $2 \mathrm{~h}$. The solution was then allowed to warm to ambient temperature and stirred for another $2 \mathrm{~h}$. All volatiles were removed in vacuum and $\mathbf{1}$ and $\mathbf{2}$ were obtained after extraction of the solid residue with toluene and evaporation of the solvent under vacuum as a red-brown waxy (1) and orange crystalline compound (2), respectively.

\subsection{1 $\mathrm{L}^{1} \mathrm{GeN}\left(\mathrm{SiMe}_{3}\right)_{2} 1$}

Yield: $0.501 \mathrm{~g}(96 \%)$. - Elemental analysis: calcd. (found): C 41.9 (41.9), H 7.7 (7.4), N 10.2 (10.0). - ${ }^{1} \mathrm{H}$ NMR (300 MHz, $\left.\mathrm{C}_{6} \mathrm{D}_{6}, 25^{\circ} \mathrm{C}\right): \delta=0.44\left(\mathrm{~s}, 18 \mathrm{H}, \mathrm{Si}\left(\mathrm{CH}_{3}\right)_{3}\right), 1.38\left(\mathrm{~s}, 3 \mathrm{H}, \mathrm{NCCH}_{3}\right)$, $1.67\left(\mathrm{~s}, 3 \mathrm{H}, \mathrm{OCCH}_{3}\right), 2.01\left(\mathrm{~s}, 6 \mathrm{H}, \mathrm{N}\left(\mathrm{CH}_{3}\right)_{2}\right), 2.34(\mathrm{~m}, 2 \mathrm{H}$, $\left.\mathrm{CH}_{2} \mathrm{CH}_{2} \mathrm{NMe}_{2}\right), 3.07\left(\mathrm{~m}, 1 \mathrm{H}, \mathrm{CH}_{2} \mathrm{CH}_{2} \mathrm{NMe}_{2}\right), 3.42(\mathrm{~m}, 1 \mathrm{H}$, $\left.\mathrm{CH}_{2} \mathrm{CH}_{2} \mathrm{NMe}_{2}\right), 4.60(\mathrm{~s}, 1 \mathrm{H}, \mathrm{CH}) .-{ }^{13} \mathrm{C}$ NMR $\left(75 \mathrm{MHz}, \mathrm{C}_{6} \mathrm{D}_{6}\right.$, $\left.25^{\circ} \mathrm{C}\right): \delta=5.2\left(\mathrm{Si}\left(\mathrm{CH}_{3}\right)_{3}\right), 20.6\left(\mathrm{NCCH}_{3}\right), 25.2\left(\mathrm{OCCH}_{3}\right), 45.1$ $\left(\mathrm{CH}_{2} \mathrm{CH}_{2} \mathrm{NMe}_{2}\right), 45.6\left(\mathrm{CH}_{2} \mathrm{CH}_{2} \mathrm{~N}\left(\mathrm{CH}_{3}\right)_{2}\right), 58.1\left(\mathrm{CH}_{2} \mathrm{CH}_{2} \mathrm{NMe}_{2}\right)$, $99.3(\mathrm{CH}), 168.0\left(\mathrm{NCCH}_{3}\right), 174.7\left(\mathrm{OCCH}_{3}\right)$. - IR (ATR): $v=2962,2819,2769,1738,1610,1575,1513,1455,1259,1088$, 1015, 864, 795, 702, 540, $397 \mathrm{~cm}^{-1}$.

\subsection{2 $\mathrm{L}^{4} \mathrm{GeN}\left(\mathrm{SiMe}_{3}\right)_{2} 2$}

Yield: $0.581 \mathrm{~g},(91 \%)$. - Elemental analysis: calcd. (found): C 54.1 (53.6), H 7.9 (8.5), N 5.1 (5.3). - ${ }^{1} \mathrm{H}$ NMR (300 MHz, $\left.\mathrm{C}_{6} \mathrm{D}_{6}, 25^{\circ} \mathrm{C}\right): \delta=0.31\left(\mathrm{~s}, 18 \mathrm{H}, \mathrm{Si}\left(\mathrm{CH}_{3}\right)_{3}\right), 0.96\left(\mathrm{~d},{ }^{3} \mathrm{H}_{\mathrm{H}, \mathrm{H}}=6.8 \mathrm{~Hz}\right.$, $\left.3 \mathrm{H}, \mathrm{CH}\left(\mathrm{CH}_{3}\right)_{2}\right), 1.01\left(\mathrm{~d},{ }^{3} \mathrm{H}_{\mathrm{H}, \mathrm{H}}=6.8 \mathrm{~Hz}, 3 \mathrm{H}, \mathrm{CH}\left(\mathrm{CH}_{3}\right)_{2}\right), 1.30(\mathrm{~s}$, $\left.3 \mathrm{H}, \mathrm{NCCH}_{3}\right), 1.33\left(\mathrm{~d},{ }^{3} \mathrm{H}_{\mathrm{H}, \mathrm{H}}=6.9 \mathrm{~Hz}, 3 \mathrm{H}, \mathrm{CH}\left(\mathrm{CH}_{3}\right)_{2}\right), 1.41$ (d, $\left.{ }^{3} J_{\mathrm{H}, \mathrm{H}}=6.9 \mathrm{~Hz}, 3 \mathrm{H}, \mathrm{CH}\left(\mathrm{CH}_{3}\right)_{2}\right), 1.74\left(\mathrm{~s}, 3 \mathrm{H}, \mathrm{OCCH}_{3}\right), 3.18$ (sept, $\left.{ }^{3} J_{\mathrm{H}, \mathrm{H}}=6.8 \mathrm{~Hz}, 1 \mathrm{H}, \mathrm{CH}\left(\mathrm{CH}_{3}\right)_{2}\right), 3.29\left(\mathrm{sept},{ }^{3} \mathrm{H}_{\mathrm{H}, \mathrm{H}}=6.9 \mathrm{~Hz}, 1 \mathrm{H}\right.$, $\left.\mathrm{CH}\left(\mathrm{CH}_{3}\right)_{2}\right), 4.86(\mathrm{~s}, 1 \mathrm{H}, \mathrm{CH}), 7.02-7.11 \mathrm{ppm}(3 \mathrm{H}, \mathrm{m} / \mathrm{p}-\mathrm{CH}$, overlapped with solvent signal). ${ }^{13} \mathrm{C} \mathrm{NMR}\left(75 \mathrm{MHz}, \mathrm{C}_{6} \mathrm{D}_{6}\right.$, $\left.25^{\circ} \mathrm{C}\right): \delta=5.5\left(\mathrm{Si}\left(\mathrm{CH}_{3}\right)_{3}\right), 23.1,24.3,24.5,24.7,24.8,25.4,27.7$, 28.8, 97.3 (backbone- $\mathrm{CH}), 124.3(\mathrm{~m}-\mathrm{CH}), 124.6(\mathrm{~m}-\mathrm{CH}), 139.1$ (p-CH), 142.6 (p-CH), 142.8 (arom. dipp- $\mathrm{CH}), 169.8\left(\mathrm{NCCH}_{3}\right)$, $176.1\left(\mathrm{OCCH}_{3}\right)$. - IR (ATR): $v=3058,2960,2900,2868,1597$, 1572, 1507, 1460, 1441, 1386, 1364, 1324, 1257, 1243, 1217, 
$1176,1099,1056,1017,913,866,833,789,770,758,703,670$, $630,618,555,510,445,411 \mathrm{~cm}^{-1}$.

\subsection{General synthesis of tin complexes $\mathrm{L}^{1-4} \mathrm{SnN}\left(\mathrm{SiMe}_{3}\right)_{2}$}

A solution of $\mathrm{LH}\left(\mathrm{L}^{1} \mathrm{H}: 0.750 \mathrm{~g}, 4.4 \mathrm{mmol} ; \mathrm{L}^{2} \mathrm{H}: 0.451 \mathrm{~g}\right.$, $2.3 \mathrm{mmol} ; \mathrm{L}^{3} \mathrm{H}: 0.800 \mathrm{~g}, 4.3 \mathrm{mmol} ; \mathrm{L}^{4} \mathrm{H}: 1.000 \mathrm{~g}, 3.9 \mathrm{mmol}$ ) in $15 \mathrm{~mL}$ of hexane was added slowly to a solution of $\mathrm{Sn}\left[\mathrm{N}\left(\mathrm{SiMe}_{3}\right)_{2}\right]_{2}(1.936 \mathrm{~g}, 4.4 \mathrm{mmol})$ in $15 \mathrm{~mL}$ of hexane at $0^{\circ} \mathrm{C}$ and stirred for $2 \mathrm{~h}$. The solution was allowed to warm to ambient temperature, stirred for additional $2 \mathrm{~h}$ and then evaporated to dryness in vacuum. The heteroleptic complexes 3-6 were obtained as red waxy (3), red-brown waxy $(4,5)$ and yellow-orange crystalline solids (6), respectively, after extraction with toluene and removal of all volatiles in vacuum.

\subsection{1 $\mathrm{L}^{1} \mathrm{SnN}\left(\mathrm{SiMe}_{3}\right)_{2} 3$}

Yield: $1.569 \mathrm{~g}(80 \%)$. - Elemental analysis: calcd. (found): C 37.3 (37.5), H 6.8 (6.5), N 8.4 (8.2). - ${ }^{1} \mathrm{H}$ NMR (300 MHz, $\left.\mathrm{C}_{6} \mathrm{D}_{6}, 25^{\circ} \mathrm{C}\right): \delta=0.46\left(\mathrm{~s}, 18 \mathrm{H}, \mathrm{Si}\left(\mathrm{CH}_{3}\right)_{3}\right), 1.36\left(\mathrm{~s}, 3 \mathrm{H}, \mathrm{NCCH}_{3}\right)$, $1.86\left(\mathrm{~s}, 3 \mathrm{H}, \mathrm{OCCH}_{3}\right), 1.94\left(\mathrm{~s}, 6 \mathrm{H}, \mathrm{N}\left(\mathrm{CH}_{3}\right)_{2}\right), 2.25(\mathrm{~m}, 2 \mathrm{H}$, $\left.\mathrm{CH}_{2} \mathrm{CH}_{2} \mathrm{NMe}_{2}\right), 2.70\left(\mathrm{~m}, 1 \mathrm{H}, \mathrm{CH}_{2} \mathrm{CH}_{2} \mathrm{NMe}_{2}\right), 2.95(\mathrm{~m}, 1 \mathrm{H}$, $\mathrm{CH}_{2} \mathrm{CH}_{2} \mathrm{NMe}_{2}$ ), $4.72(\mathrm{~s}, 1 \mathrm{H}, \mathrm{CH}) .{ }^{13} \mathrm{C}$ NMR $\left(75 \mathrm{MHz}, \mathrm{C}_{6} \mathrm{D}_{6}\right.$, $\left.25^{\circ} \mathrm{C}\right): \delta=6.6\left(\mathrm{Si}\left(\mathrm{CH}_{3}\right)_{3}\right), 23.2\left(\mathrm{NCCH}_{3}\right), 27.5\left(\mathrm{OCCH}_{3}\right), 44.9$ $\left(\mathrm{CH}_{2} \mathrm{CH}_{2} \mathrm{NMe}_{2}\right), 47.5\left(\mathrm{~N}\left(\mathrm{CH}_{3}\right)_{2}\right), 58.2\left(\mathrm{CH}_{2} \mathrm{CH}_{2} \mathrm{NMe}_{2}\right), 99.2$ $(\mathrm{CH}), 170.2\left(\mathrm{NCCH}_{3}\right), 180.9\left(\mathrm{OCCH}_{3}\right) .-{ }^{119} \mathrm{Sn} \mathrm{NMR}(111.9 \mathrm{MHz}$, $\mathrm{C}_{6} \mathrm{D}_{6}, 25^{\circ} \mathrm{C}$ ): $\delta=-221.4$. - IR (ATR): $v=3055,2952,2860$, 2819, 2770, 1646, 1603, 1567, 1508, 1455, 1422, 1393, 1340, $1246,1175,1124,1097,1016,927,867,836,780,780,758,668$, $618,509,411,392 \mathrm{~cm}^{-1}$.

\subsection{2 $\mathrm{L}^{2} \mathrm{SnN}\left(\mathrm{SiMe}_{3}\right)_{2} 4$}

Yield: $0.834 \mathrm{~g}(76 \%)$. - Elemental analysis: calcd. (found): C 40.4 (41.0), H 6.5 (6.7), N 8.4 (8.7). - ' ${ }^{1} \mathrm{H}$ NMR (300 MHz, $\left.\mathrm{C}_{6} \mathrm{D}_{6}, 25^{\circ} \mathrm{C}\right): \delta=0.43\left(\mathrm{~s}, 18 \mathrm{H}, \mathrm{Si}\left(\mathrm{CH}_{3}\right)_{3}\right), 0.86\left(\mathrm{t},{ }^{3} J_{\mathrm{H}, \mathrm{H}}=7.1 \mathrm{~Hz}\right.$, $\left.6 \mathrm{H}, \mathrm{N}\left(\mathrm{CH}_{2} \mathrm{CH}_{3}\right)_{2}\right), 1.46\left(\mathrm{~s}, 3 \mathrm{H}, \mathrm{NCCH}_{3}\right), 1.82\left(\mathrm{~s}, 3 \mathrm{H}, \mathrm{OCCH}_{3}\right)$, $2.36\left(\mathrm{~m}, 6 \mathrm{H}, \mathrm{N}\left(\mathrm{CH}_{2} \mathrm{CH}_{3}\right)_{2}\right.$ overlapped with $\left.\mathrm{CH}_{2} \mathrm{CH}_{2} \mathrm{NEt}_{2}\right)$, $3.06\left(\mathrm{~m}, 1 \mathrm{H}, \mathrm{CH}_{2} \mathrm{CH}_{2} \mathrm{NEt}_{2}\right), 3.32\left(\mathrm{~m}, 1 \mathrm{H}, \mathrm{CH}_{2} \mathrm{CH}_{2} \mathrm{NEt}_{2}\right)$, $4.70(\mathrm{~s}, 1 \mathrm{H}, \mathrm{CH}) .-{ }^{13} \mathrm{C}$ NMR $\left(75 \mathrm{MHz}, \mathrm{C}_{6} \mathrm{D}_{6}, 25^{\circ} \mathrm{C}\right): \delta=6.6$

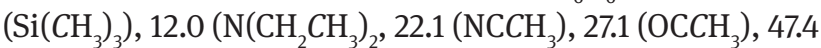
$\left(\mathrm{N}\left(\mathrm{CH}_{2} \mathrm{CH}_{3}\right)_{2}\right), 48.4\left(\mathrm{CH}_{2} \mathrm{CH}_{2} \mathrm{NEt}_{2}\right), 53.1\left(\mathrm{CH}_{2} \mathrm{CH}_{2} \mathrm{NEt}_{2}\right), 100.2$ (CH), $169.9\left(\mathrm{NCCH}_{3}\right), 177.8\left(\mathrm{OCCH}_{3}\right) .-{ }^{119} \mathrm{Sn} \mathrm{NMR}(111.9 \mathrm{MHz}$, $\left.\mathrm{C}_{6} \mathrm{D}_{6}, 25^{\circ} \mathrm{C}\right): \delta=-150.7 .-$ IR (ATR): $v=2964,2933,2872$, 2809, 1647, 1608, 1565, 1510, 1467, 1438, 1397, 1372, 1341,
1286, 1248, 1200, 1176, 1124, 1065, 1015, 928, 883, 837, 821, $755,733,668,617,501,395 \mathrm{~cm}^{-1}$

\subsection{3 $\mathrm{L}^{3} \mathrm{SnN}\left(\mathrm{SiMe}_{3}\right)_{2} 5$}

Yield: $1.597 \mathrm{~g}(81 \%)$. - Elemental analysis: calcd. (found): C 40.8 (41.1), H 6.4 (6.5), N 9.7 (9.5). - ' $\mathrm{H}$ NMR (300 MHz, $\left.\mathrm{C}_{6} \mathrm{D}_{6}, 25^{\circ} \mathrm{C}\right): \delta=0.41\left(\mathrm{~s}, 18 \mathrm{H}, \mathrm{Si}\left(\mathrm{CH}_{3}\right)_{3}\right), 1.46\left(\mathrm{~s}, 3 \mathrm{H}, \mathrm{NCCH}_{3}\right)$, $1.52\left(\mathrm{~m},{ }^{3} \mathrm{H}_{\mathrm{H}, \mathrm{H}}=7.0 \mathrm{~Hz}, 2 \mathrm{H}, \mathrm{CH}_{2} \mathrm{CH}_{2} \mathrm{CH}_{2} \mathrm{NMe}_{2}\right), 1.81(\mathrm{~s}, 3$ $\left.\mathrm{H}, \mathrm{OCCH}_{3}\right), 1.98\left(\mathrm{~s}, 6 \mathrm{H}, \mathrm{N}\left(\mathrm{CH}_{3}\right)_{2}\right), 2.06\left(\mathrm{~m}, 2 \mathrm{H}, \mathrm{CH}_{2} \mathrm{CH}_{2}-\right.$ $\left.\mathrm{CH}_{2} \mathrm{NMe}_{2}\right), 3.08\left(\mathrm{~m}, 1 \mathrm{H}, \mathrm{CH}_{2} \mathrm{CH}_{2} \mathrm{CH}_{2} \mathrm{NMe}_{2}\right), 3.39(\mathrm{~m}, 1 \mathrm{H}$, $\left.\mathrm{CH}_{2} \mathrm{CH}_{2} \mathrm{CH}_{2} \mathrm{NMe}_{2}\right), 4.69(\mathrm{~s}, 1 \mathrm{H}, \mathrm{CH}) .-{ }^{13} \mathrm{C} \mathrm{NMR}\left(75 \mathrm{MHz}, \mathrm{C}_{6} \mathrm{D}_{6}\right.$, $\left.25^{\circ} \mathrm{C}\right): \delta=4.35\left(\mathrm{Si}\left(\mathrm{CH}_{3}\right)_{3}\right), 25.0\left(\mathrm{NCCH}_{3}\right), 26.3\left(\mathrm{OCCH}_{3}\right), 27.9$ $\left(\mathrm{CH}_{2} \mathrm{CH}_{2} \mathrm{CH}_{2} \mathrm{NMe}_{2}\right), 43.8\left(\mathrm{CH}_{2} \mathrm{CH}_{2} \mathrm{CH}_{2} \mathrm{NMe}_{2}\right), 44.6\left(\mathrm{~N}\left(\mathrm{CH}_{3}\right)_{2}\right)$, $55.0\left(\mathrm{CH}_{2} \mathrm{CH}_{2} \mathrm{CH}_{2} \mathrm{NMe}_{2}\right), 98.4(\mathrm{CH}), 167.4\left(\mathrm{NCCH}_{3}\right), 175.0$ $\left(\mathrm{OCCH}_{3}\right) .-{ }^{119} \mathrm{Sn}$ NMR $\left(111.9 \mathrm{MHz}, \mathrm{C}_{6} \mathrm{D}_{6}, 25^{\circ} \mathrm{C}\right): \delta=-133.1 .-$ IR (ATR): $v=2938,2855,2812,2762,1645,1608,1559,1510$, 1457, 1440, 1399, 1372, 1336, 1299, 1259, 1219, 1178, 1151, 1121, 1096, 1061, 1039, 965, 932, 820, 803, 743, 501, $460 \mathrm{~cm}^{-1}$.

\subsection{4 $\mathrm{L}^{4} \mathrm{SnN}\left(\mathrm{SiMe}_{3}\right)_{2} 6$}

Yield: $1.398 \mathrm{~g}$ (67\%). - Elemental analysis: calcd. (found): H 51.3 (51.7), C 7.7 (8.0), N 5.3 (5.2). - ${ }^{1} \mathrm{H}$ NMR (300 MHz, $\left.\mathrm{C}_{6} \mathrm{D}_{6}, 25^{\circ} \mathrm{C}\right): \delta=0.30\left(\mathrm{~s}, 18 \mathrm{H}, \mathrm{Si}\left(\mathrm{CH}_{3}\right)_{3}\right), 0.96\left(\mathrm{~d},{ }^{3} J_{\mathrm{H}, \mathrm{H}}=6.7 \mathrm{~Hz}\right.$, $\left.3 \mathrm{H}, \mathrm{CH}\left(\mathrm{CH}_{3}\right)_{2}\right), 1.05\left(\mathrm{~d},{ }^{3} \mathrm{H}_{\mathrm{H}, \mathrm{H}}=6.8 \mathrm{~Hz}, 3 \mathrm{H}, \mathrm{CH}\left(\mathrm{CH}_{3}\right)_{2}\right), 1.22$ $\left(\mathrm{d},{ }^{3} J_{\mathrm{H}, \mathrm{H}}=6.7 \mathrm{~Hz}, 3 \mathrm{H}, \mathrm{CH}\left(\mathrm{CH}_{3}\right)_{2}\right), 1.37\left(\mathrm{~s}, 3 \mathrm{H}, \mathrm{NCCH}_{3}\right), 1.43$ $\left(\mathrm{d},{ }^{3} J_{\mathrm{H}, \mathrm{H}}=6.8 \mathrm{~Hz}, 3 \mathrm{H}, \mathrm{CH}\left(\mathrm{CH}_{3}\right)_{2}\right), 1.86\left(\mathrm{~s}, 3 \mathrm{H}, \mathrm{OCCH}_{3}\right), 2.99$ (sept, $\left.{ }^{3} J_{\mathrm{H}, \mathrm{H}}=6.6 \mathrm{~Hz}, 1 \mathrm{H}, \mathrm{CH}\left(\mathrm{CH}_{3}\right)_{2}\right), 3.32\left(\mathrm{sept},{ }^{3} J_{\mathrm{H}, \mathrm{H}}=6.4 \mathrm{~Hz}\right.$, $\left.1 \mathrm{H}, \mathrm{CH}\left(\mathrm{CH}_{3}\right)_{2}\right), 4.86(\mathrm{~s}, 1 \mathrm{H}, \mathrm{CH}), 6.95-7.25(\mathrm{~m}, 3 \mathrm{H}, \mathrm{m} / p$ $\mathrm{CH}$, overlapped with solvent signal). ${ }^{13} \mathrm{C}$ NMR $(75 \mathrm{MHz}$, $\left.\mathrm{C}_{6} \mathrm{D}_{6}, 25^{\circ} \mathrm{C}\right): \delta=6.7\left(\mathrm{Si}\left(\mathrm{CH}_{3}\right)_{3}\right), 24.2,24.3,24.9,25.4,25.6$, 27.4, 28.3, 29.2, 98.9 (CH), 125.1 (dipp-CH), 125.3 (dipp-CH), 126.0, 141.1 (dipp-CH), 142.1 (dipp-CH), 143.7 (dipp-CH), $171.4\left(\mathrm{NCCH}_{3}\right), 179.2\left(\mathrm{OCCH}_{3}\right) .{ }^{119} \mathrm{Sn}$ NMR $\left(111.9 \mathrm{MHz}, \mathrm{C}_{6} \mathrm{D}_{6}\right.$, $25^{\circ} \mathrm{C}$ ): $\delta=-88.8$. - IR (ATR): $v=3055,2962,2896,2869$, 1723, 1575, 1502, 1460, 1440, 1386, 1364, 1322, 1240, 1176, $1101,1054,1042,1014,937,864,831,795,774,758,689,668$, $614,595,529,506,439,405 \mathrm{~cm}^{-1}$.

\subsection{Synthesis of $\mathrm{L}^{1} M g L^{5} 7$}

A mixture of 3 (94 mg, $0.2 \mathrm{mmol})$ and $\left[\mathrm{L}^{5} \mathrm{Mg}\right]_{2}(186 \mathrm{mg}$, $0.2 \mathrm{mmol}$ ) was dissolved at $0^{\circ} \mathrm{C}$ in $5 \mathrm{~mL}$ of toluene and stirred for $48 \mathrm{~h}$ at ambient temperature. The solvent was evaporated from the dark red-brown solution and the resulting crystalline solid was dissolved in pentane. Slightly orange crystals of 7 were formed within $2 \mathrm{~d}$ upon 
storage at $-30^{\circ} \mathrm{C}$. Yield: $30 \mathrm{mg}(25 \%)$. - Elemental analysis: calcd. (found): C 74.7 (74.6), H 9.6 (9.7), N 9.2 (9.2). ${ }^{1} \mathrm{H} \mathrm{NMR}$ (300 MHz, $\left.\mathrm{C}_{6} \mathrm{D}_{6}\right): \delta=1.21\left(\mathrm{~d},{ }^{3} J_{\mathrm{HH}}=7.4 \mathrm{~Hz}, 6 \mathrm{H}, \mathrm{CH}\left(\mathrm{CH}_{3}\right)_{2}\right)$, 1.26-1.35 (overlapping douplets, $\left.18 \mathrm{H}, \mathrm{CH}\left(\mathrm{CH}_{3}\right)_{2}\right), 1.59$ (s, 3 $\left.\mathrm{H}, \mathrm{NCCH}_{3}\left(\mathrm{~L}^{1}\right)\right), 1.72\left(\mathrm{~s}, 6 \mathrm{H}, \mathrm{CH}_{3}\left(\mathrm{~L}^{5}\right)\right), 1.79\left(\mathrm{~s}, 6 \mathrm{H}, \mathrm{N}\left(\mathrm{CH}_{3}\right)_{2}\right)$, 1.96 (s, $\left.3 \mathrm{H}, \mathrm{OCCH}_{3}\left(\mathrm{~L}^{1}\right)\right), 2.78\left(\mathrm{~m}, 2 \mathrm{H}, \mathrm{CH}_{2} \mathrm{CH}_{2} \mathrm{NMe}_{2}\right.$ ), 3.49 (m, $4 \mathrm{H}$, overlapping signals $\mathrm{CH}_{2} \mathrm{CH}_{2} \mathrm{NMe}_{2}$ and $\mathrm{CH}\left(\mathrm{CH}_{3}\right)_{2}$ ), 4.89 (s, 1 H, CH (L)), 5.09 (s, 1 H, CH (L) )), 7.01-7.20 (m, 3 $\mathrm{H}, m / p-\mathrm{CH}$, overlapping with solvent signals). $-{ }^{13} \mathrm{C}$ NMR $\left(75 \mathrm{MHz}, \mathrm{C}_{6} \mathrm{D}_{6}, 25^{\circ} \mathrm{C}\right): \delta=21.9,22.6,23.5,24.2,24.5,24.9$, 25.2, 25.3, 27.4, 28.2, 28.5, 28.6, 45.4, 46.2, 59.5, $96.9(\mathrm{CH})$, $97.7(\mathrm{CH}), 123.4,123.6,123.9,124.0,124.7,125.9,142.4$ (dipp$\mathrm{CH}), 142.8$ (dipp- $\mathrm{CH}), 143.5$ (dipp- $\mathrm{CH}), 148.1,161.6\left(\mathrm{NCCH}_{3}\right.$ ), $168.3\left(\mathrm{NCCH}_{3}\right), 173.2\left(\mathrm{NCCH}_{3}\right), 182.7\left(\mathrm{OCCH}_{3}\right)$. - IR (ATR): $v=3053,2959,2922,2865,1621,1581,1537,1516,1458,1430$, 1400, 1337, 1312, 1261, 1225, 1172, 1098, 1052, 1014, 925, $841,789,759,734,699,668,646,622,596,548,516,435$, $417 \mathrm{~cm}^{-1}$.

\subsection{Reaction of 2 with $\left[\mathrm{L}^{5} \mathrm{Mg}\right]_{2}$}

Compound 2 (15 mg, $0.03 \mathrm{mmol})$ and $\left[\mathrm{L}^{5} \mathrm{Mg}\right]_{2}(13 \mathrm{mg}$, $0.015 \mathrm{mmol}$ ) were dissolved at $-10^{\circ} \mathrm{C}$ in $0.5 \mathrm{~mL}$ toluene and stirred for $3 \mathrm{~h}$ at that temperature, slowly warmed up to ambient temperature and stirred for additional $12 \mathrm{~h}$. Thereafter the reaction mixture was heated to $50^{\circ} \mathrm{C}$ for $6 \mathrm{~h}$, yielding an dark solution with a black precipitate. The in-situ ${ }^{1} \mathrm{H}$ NMR spectrum of the solution showed the formation of $\mathrm{L}^{5} \mathrm{MgN}\left(\mathrm{SiMe}_{3}\right)_{2} 8$ [45]. Additional signals were either assigned to the starting reagent $\mathbf{2}$ or belong to so far unidentified products. The formation of a black solid indicates the reduction of $\mathbf{2}$ to elemental germanium 8: ${ }^{1} \mathrm{H}$ NMR (300 MHz, $\left.\mathrm{C}_{6} \mathrm{D}_{6}, 25^{\circ} \mathrm{C}\right): \delta=0.02\left(\mathrm{~s}, 18 \mathrm{H}, \mathrm{Si}\left(\mathrm{CH}_{3}\right)_{3}\right)$, $1.20\left(\mathrm{~d},{ }^{3} J_{\mathrm{H}, \mathrm{H}}=6.7 \mathrm{~Hz}, 12 \mathrm{H}, \mathrm{CH}\left(\mathrm{CH}_{3}\right)_{2}\right), 1.40\left(\mathrm{~d},{ }^{3} \mathrm{~J}_{\mathrm{H}, \mathrm{H}}=6.8 \mathrm{~Hz}\right.$, $\left.12 \mathrm{H}, \mathrm{CH}\left(\mathrm{CH}_{3}\right)_{2}\right), 1.67\left(\mathrm{~s}, 3 \mathrm{H}, \mathrm{CH}_{3}\right), 3.23\left(\mathrm{sept},{ }^{3} \mathrm{H}_{\mathrm{H}, \mathrm{H}}=6.8 \mathrm{~Hz}\right.$, $\left.4 \mathrm{H}, \mathrm{CH}\left(\mathrm{CH}_{3}\right)_{2}\right), 4.83$ (s, $\left.1 \mathrm{H}, \mathrm{CH}\right), 7.02-7.05 \mathrm{ppm}(\mathrm{m}, 6 \mathrm{H}$, $\mathrm{m} / \mathrm{p}-\mathrm{CH})$.

\subsection{Reaction of 6 with $\left[\mathrm{L}^{5} \mathrm{Mg}\right]_{2}$}

6 (64 mg, $0.1 \mathrm{mmol})$ and $\left[\mathrm{L}^{5} \mathrm{Mg}\right]_{2}(102 \mathrm{mg}, 0.1 \mathrm{mmol})$ were dissolved at $-10^{\circ} \mathrm{C}$ in $0.5 \mathrm{~mL}$ of toluene and stirred for $3 \mathrm{~h}$ at that temperature, resulting in the formation of a dark brown solution and a black precipitate. The mixture was warmed to ambient temperature and stirred for another $3 \mathrm{~h}$, upon which the color did not change. The in-situ ${ }^{1} \mathrm{H}$ NMR spectrum of the reaction solution showed the formation of $\mathrm{L}^{5} \mathrm{MgN}\left(\mathrm{SiMe}_{3}\right)_{2}$ 8. Additional signals could not been assigned to any known compound. The formation of a black solid indicates the formation of elemental tin.

\section{Crystal structure determinations}

The crystals of $\mathbf{6}$ and $\mathbf{7}$ were mounted on nylon loops in inert oil. Data were collected on a Bruker AXS D8 Kappa diffractometer with APEX2 detector (monochromated MoK $\alpha$ radiation, $\lambda=0.71073 \AA$ ). The structures were solved by Direct Methods (SHELxs-97) [51, 52] and refined anisotropically by full-matrix least-squares on $F^{2}$ (SHELXL-2014) [53-57]. Absorption corrections were performed semi-empirically from equivalent reflections on basis of multi-scans (Bruker AXS APEX2, TwINABS). Hydrogen atoms were refined using a riding model or rigid methyl groups. Compound 6 was non-merohedrally twinned and refined with two components against HKLF5 data. Compound 7 contained highly disordered solvent of unidentifiable nature. $n$-pentane, $n$-hexane and toluene were used but none of these or combinations thereof yielded a satisfying model for the residual density. Consequently, the refinement was done using "solvent-free" data from a PLATON/SQEEZE run. Because the solvent could not be identified for certain it was ignored in the sum formula. The ligands side-arm is disordered over two positions.

CCDC-1555595 (6) and CCDC-1555596 (7) contain the supplementary crystallographic data for this paper. These data can be obtained free of charge from The Cambridge Crystallographic Data Centre via www.ccdc.cam.ac.uk/ data_request/cif.

\section{Supporting Information}

${ }^{1} \mathrm{H}$ and ${ }^{13} \mathrm{C}$ NMR and IR spectra of $\mathbf{1}-\mathbf{7},{ }^{119} \mathrm{Sn}$ NMR spectra of 3-6, in situ ${ }^{1} \mathrm{H}$ NMR spectra of the reduction reaction of 2 and 6 with $\left[\mathrm{L}^{5} \mathrm{Mg}\right]_{2}$, and crystallographic data of 6 and 7 are given as Supporting Information available online (https://doi.org/10.1515/znb-2017-0098).

Acknowledgments: S. Schulz thank the University of Duisburg-Essen for financial support. J. Wiederkehr is grateful to the Fonds der Chemischen Industrie for a doctoral fellowship. Ms. Haley Palm is acknowledge for contributing to the experimental work.

\section{References}

[1] N. Tokitoh, T. Sasamori, in Comprehensive Inorganic Chemistry II, $2^{\text {nd }}$ edition, From Elements to Applications, Vol. 1

(Eds.: J. Reedijk, K. Poeppelmeier), Elsevier, Amsterdam, 2013, chapter 1.19, p. 567. 
[2] M. Asay, C. Jones, M. Driess, Chem. Rev. 2011, 111, 354.

[3] Y. Mizuhata, T. Sasamori, N. Tokitoh, Chem. Rev. 2009, 109, 3479.

[4] M. Kira, S. Ishida, T. Iwamoto, Chem. Rec. 2004, 4, 243.

[5] N. Tokitoh, R. Okazaki, Coord. Chem. Rev. 2000, 210, 251.

[6] R. S. Ghadwal, R. Azhakar, H. W. Roesky, Acc. Chem. Res. 2013, 46, 444.

[7] R. S. Ghadwal, H. W. Roesky, S. Merkel, J. Henn, D. Stalke, Angew. Chem. Int. Ed. 2009, 48, 5683.

[8] G. Trinquier, J. Am. Chem. Soc. 1990, 112, 2130.

[9] D. E. Goldberg, D. H. Harris, M. F. Lappert, K. M. Thomas, J. Chem. Soc. Chem. Commun. 1976, 7, 261.

[10] P. J. Davidson, D. H. Harris, M. F. Lappert, J. Chem. Soc. Dalton Trans. 1976, 21, 2268.

[11] P. B. Hitchcock, M. F. Lappert, S. J. Miles, A. J. Thorne, J. Chem. Soc. Chem. Commun. 1984, 7, 480.

[12] D. C. H. Do, A. Keyser, A. V. Protchenko, B. Maitland, I. Pernik, H. Niu, E. L. Kolychev, A. Rit, D. Vidovic, A. Stasch, C. Jones, S. Aldridge, Chem. Eur. J. 2017, 23, 5830.

[13] E. Ballestero-Martínez, J. Klosin, B. D. Fahlman, L. W. Pineda, Eur. J. Inorg. Chem. 2014, 5233.

[14] Y. Yang, N. Zhao, Y. Wu, H. Zhu, H. W. Roesky, Inorg. Chem. 2012, 51, 2425.

[15] L. W. Pineda, V. Jancik, K. Starke, R. B. Oswald, H. W. Roesky, Angew. Chem. Int. Ed. 2006, 45, 2602.

[16] M. Driess, S. Yao, M. Brym, C. van Wüllen, Angew. Chem. Int. Ed. 2006, 45, 4349.

[17] L. Bourget-Merle, M. F. Lappert, J. R. Severn, Chem. Rev. 2002 , 102, 3031.

[18] Y. Ding, H. W. Roesky, M. Noltemeyer, H.-G. Schmidt, P. P. Power, Organometallics 2001, 20, 1190.

[19] A. Akkari, J. J. Byrne, I. Saur, G. Rima, H. Gornitzka, J. Barrau, J. Organomet. Chem. 2001, 622, 190.

[20] K. V. Zaitsev, V. S. Cherepakhin, A. V. Churakov, A. S. Peregudov, B. N. Tarasevich, M. P. Egorov, G. S. Zaitseva, S. S. Karlov, Inorg. Chim. Acta 2016, 443, 91.

[21] H.-M. Kao, S.-M. Ho, I.-C. Chen, P.-C. Kuo, C.-Y. Lin, C.-Y. Tu, C.-H. Hu, J.-H. Huang, G.-H. Lee, Inorg. Chim. Acta. 2008, 361, 2792.

[22] J. A. Belot, A. Wang, N. L. Edleman, J. R. Babcock, M. V. Metz, T. J. Marks, P. R. Markworth, R. P. H. Chang, Mater. Res. Soc. Symp. Proc. 1999, 574, 37.

[23] Y. Wu, C. Shan, Y. Sun, P. Chen, J. Ying, J. Zhu, L. Liu, Y. Zhao, J. Chem. Soc. Chem. Commun. 2016, 52, 13799.

[24] T. J. Hadlington, M. Hermann, G. Frenking, C. Jones, J. Am. Chem. Soc. 2014, 136, 3028.

[25] L. Wang, S. Fadlallah, C. Bellini, C. Orione, V. Dorcet, J.-F. Carpentier, Y. Sarazin, Organometallics 2015, 34, 1321.

[26] L. Wang, S.-C. Rosca, V. Poirier, S. Sinbandhit, V. Dorcet, T. Roisnel, J.-F. Carpentier, Y. Sarazin, J. Chem. Soc. Dalton Trans. 2014, 43, 4268.

[27] L. Wang, V. Poirier, F. Ghiotto, M. Bochmann, R. D. Cannon, J.-F. Carpentier, Y. Sarazin, Macromol. 2014, 47, 2574.

[28] L. Pu, A. D. Phillips, P. P. Power, J. Am. Chem. Soc. 2003, 125, 11626.

[29] M. Brynda, R. Herber, P. B. Hitchcock, M. F. Lappert, I. Nowik, P. P. Power, A. V. Protchenko, A. Ruzicka, J. Steiner, Angew. Chem. Int. Ed. 2006, 45, 4333.

[30] D. L. Kays, Chem. Soc. Rev. 2016, 45, 1004.

[31] R. C. Fischer, P. P. Power, Chem. Rev. 2010, 110, 3877.
[32] H. Lei, J. C. Fettinger, P. P. Power, Organometallics 2010, 29, 5585.

[33] P. P. Power, Organometallics 2007, 26, 4362.

[34] B. E. Eichler, P. P. Power, Angew. Chem. Int. Ed. 2001, 40, 796.

[35] O. Kysliak, C. Schrenk, A. Schnepf, Angew. Chem. Int. Ed. 2016, $55,3216$.

[36] C. Schrenk, F. Winter, R. Pöttgen, A. Schnepf, Chem. Eur. J. 2015, 21, 2992.

[37] C. Schrenk, B. Gerke, R. Pöttgen, A. Clayborne, A. Schnepf, Chem. Eur. J. 2015, 21, 8222.

[38] A. Schnepf, Chem. Soc. Rev. 2007, 36, 745.

[39] J. Wiederkehr, C. Wölper, S. Schulz, J. Chem. Soc. Chem. Commun. 2016, 52, 12282.

[40] CSD (Version 5.38) analysis: search for $\mathrm{MeC}(\mathrm{N}) \mathrm{CC}(0) M e$ with hetero atoms bonded to $\mathrm{Sn}$. All bonds were defined as "any". Average Sn-N 2.183(73) ̊ (2.1 to 2.409 $\mathrm{A}$ ) and average Sn-0 2.107(43) $\AA$ ( 2.042 to $2.195 \AA$ ) bond lengths are based on 23 bonds from 17 hits.

[41] F. H. Allen, Acta Crystallogr. 2002, B58, 380.

[42] CSD (Version 5.38) analysis: search for $\mathrm{Sn} \cdots \mathrm{N}\left(\mathrm{SiMe}_{3}\right)_{2}$ with $\mathrm{Sn}-\mathrm{N}$ and Si-N bonds of type "any". Average Sn-N 2.083(52) $\AA$ (1.899 to $2.414 \AA$ ) based on 245 bonds from 121 hits. See also: F. H. Allen, Acta Crystallogr. 2002, B58, 380.

[43] S. P. Green, C. Jones, A. Stasch, Science 2007, 318, 1754.

[44] S. J. Bonyhady, C. Jones, S. Nembenna, A. Stasch, A. J. Edwards, G. J. McIntyre, Chem. Eur. J. 2010, 16, 938.

[45] B. M. Chamberlain, M. Cheng, D. R. Moore, T. M. Ovitt, E. B. Lobkovsky, G. W. Coates, J. Am. Chem. Soc. 2001, 123, 3229.

[46] CSD (Version 5.38) analysis: search with pattern analog to Sn search. Average Mg-0 1.990(54) $\AA$ (1.895 to $2.095 \AA$ ), average Mg-N $2.144 \AA$ ( 2.059 to $2.21 \AA$ ) based on 28 bonds each from 15 hits. The corresponding search for the $L^{5}$ backbone yielded 275 hit (818 bonds): average Mg-N 2.060(35) $\AA$ (1.994 to $2.237 \AA$ ).

[47] R. K. Harris, E. D. Becker, S. M. Cabral de Menezes, R. Goodfellow, P. Granger, Magn. Reson. Chem. 2002, 40, 489.

[48] C. Scheiper, PhD thesis, University of Duisburg-Essen, Essen (Germany), 2015.

[49] D. Neculai, H. W. Roesky, A. M. Neculai, J. Magull, H. G. Schmidt, M. Noltemeyer, J. Organomet. Chem. 2002, 643-644, 47.

[50] Y. Yao, M. Xue, Y. Luo, Z. Zhang, R. Jiao, Y. Zhang, Q. Shen, W. Wong, K. Yu, J. Sun, J. Organomet. Chem. 2003, 678, 108.

[51] G. M. Sheldrick, SHELXS-97, Program for the Solution of Crystal Structures, University of Göttingen, Göttingen (Germany), 1997.

[52] G. M. Sheldrick, Acta Crystallogr. 1990, A46, 467.

[53] G. M. Sheldrick, SHeLXL-2014, Program for the Refinement of Crystal Structures, University of Göttingen, Göttingen (Germany), 2014.

[54] G. M. Sheldrick, Acta Crystallogr. 2008, A64, 112.

[55] G. M.Sheldrick, Acta Crystallogr. 2015, C71, 3.

[56] C. B. Hübschle, G. M. Sheldrick, B. Dittrich, ShelXLE, A Qt graphical user interface for SHELXL, University of Göttingen, Göttingen (Germany), 2011.

[57] C. B. Hübschle, G. M. Sheldrick, B. Dittrich, J. Appl. Crystallogr. 2011, 44, 1281.

Supplemental Material: The online version of this article offers supplementary material (https://doi.org/10.1515/znb-2017-0098). 


\section{Graphical synopsis}

Jessica Wiederkehr, Christoph Wölper and

Stephan Schulz

Synthesis, solid-state structures and

reduction reactions of heteroleptic $\mathrm{Ge}$ (II)

and $\mathrm{Sn}$ (II) $\beta$-ketoiminate complexes

https://doi.org/10.1515/znb-2017-0098

Z. Naturforsch. 2017; x(x)b: xxx-xxx

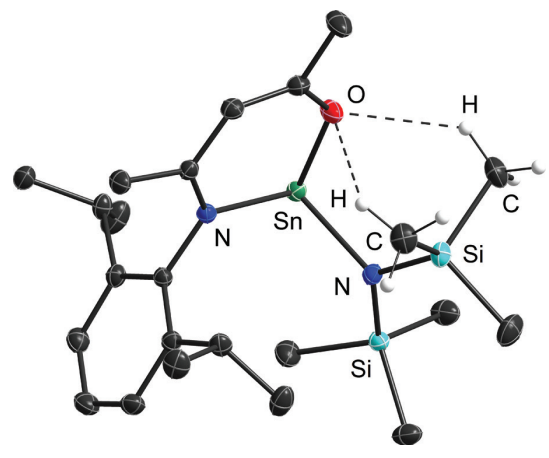




\section{DuEPublico}

DEU ISSBE R R G

Duisburg-Essen Publications online

offen im Denken

$\mathbf{U b} \mid \begin{gathered}\text { universitäts } \\ \text { bibliothek }\end{gathered}$

This text is made available via DuEPublico, the institutional repository of the University of Duisburg-Essen. This version may eventually differ from another version distributed by a commercial publisher.

DOI: $\quad 10.1515 / \mathrm{znb}-2017-0098$

URN: urn:nbn:de:hbz:464-20201210-180408-9

This is a postprint version of an article that was published in:

Zeitschrift für Naturforschung B 2017, 72, 813-820.

The final version is available at: https://doi.org/10.1515/znb-2017-0098

All rights reserved. C2017 Walter de Gruyter GmbH, Berlin/Boston. 